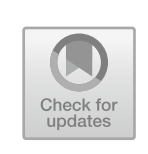

\title{
The United States: The First Formalization of Banking Supervision
}

\subsection{INTRODUCTION}

The federal political structure in the United States (US) has influenced the character of the country's banking system ever since independence. The dual-banking system whereby state and federal chartered banks have coexisted under somewhat different regulations and supervision is a product of the reforms that formalized banking supervision during the Civil War. Whereas the US financial sector is broadly categorized as a liberal market-oriented system in which market discipline (rather than regulatory enforcement) works well (Allen and Gale 2000; Hall and Soskice 2001), it has also been characterized by formal regulation and supervision for much longer than the systems in most other countries. As we will see, many US states introduced state-level banking supervisory systems in the early nineteenth century, and with the creation of the Office of the Comptroller of the Currency (OCC) and the enactment of the National Bank Act of 1864, the US became the first country to introduce formal banking supervision at the federal level. Previous studies have found that state banking supervision before 1864 and national banking supervision before the New Deal were both characterized by a "light touch," and were thus imperfect in terms of their effectiveness (White 2011; Mitchener and Jaremski 2014). White found that the relatively small losses caused by a series of financial crises in the late nineteenth century were the result of the double liability rule under which shareholders were compelled to pay double the amount of their investment, and that banking supervision was seen as a

(C) The Author(s) 2022

E. Hotori et al., Formalization of Banking Supervision, https://doi.org/10.1007/978-981-16-6783-1_2 
"complementary factor" supporting the self-discipline and governance of the commercial banks (White 2015: 22-23).

Basically, this chapter draws on the findings of important previous studies. In particular, White's $(2015)^{1}$ novel study covered the key elements of banking supervision by the OCC based on archival materials from related institutions and is therefore highly relevant. In addition to examining such studies, this chapter also challenges the common perspective regarding the driver of formalization of banking supervision. In our view, previous studies have assumed a close link between financial crises and the introduction of bank regulation/supervision. ${ }^{2}$ However, as Hotori and Wendschlag (2019) showed, a financial crisis has not always been the sole driver of the formalization of banking supervision.

Drawing on two historical studies (Knox [1900] and Allen et al. [1938]), this chapter examines the formalization of banking supervision in the US, in particular banking supervision by the OCC. Based on the criteria introduced in the previous chapter, the OCC supervisory system was the first and most important banking supervisory system during the period in question. ${ }^{3}$ Regarding banking supervision at the state level, we focus on New York State (NY) because its supervisory system provided the foundation for the system of banking supervision introduced by the OCC.

\subsection{EARLY DEVELOPMENT of Commercial BANKING IN THE US}

Commercial banking first emerged at the state level in the US and hence developed somewhat differently in different parts of the country. ${ }^{4}$ Following the Declaration of Independence in 1776, commercial (state) banks were established in Philadelphia in 1782 (The Bank of North America), Boston in 1784 (Massachusetts Bank), and New York in 1784 (The Bank of New York). The First Bank of the US was chartered by

\footnotetext{
${ }^{1}$ See also Stiller (2017).

${ }^{2}$ For example, Gigliobianco and Toniolo (2009).

${ }^{3}$ As illustrated in the next chapter, the OCC system was the model for the formalization of banking supervision in Japan.

${ }^{4}$ Besides state banks and national banks, the US banking system comprises savings banks and trust companies.
} 
the federal government in $1791 .^{5}$ During the 30 -year period from 1800 to 1830 , the number of state banks in the US increased from 28 to 330 (Knox 1900: 307-310).

An early feature of commercial banking in the US was the right to issue notes with official (state) approval. Approximately 9,000 different banknotes issued by more than 1,500 state banks were in circulation by 1860 (Robertson 1968: 29-32). Noteholders suffered losses if the issuing bank failed, and yet the number of people who suffered losses was relatively small (Rockoff 1974, 1975).

From the late 1830s until the introduction of the National Bank Act of 1864, the "free banking era" has been perceived as one of the most distinctive features of the financial history of the US (Hammond 1957: 572-604). The term "free" meant that anyone who so desired could create a bank without obtaining a charter from any authority. Except for an initial failure in Michigan (as a result of the well-known "wildcat" banking problem), the free banking system was successful (Rockoff 1974: 141-143, 163). Notably, chartered banks existed alongside these free banks, which led to fierce competition in many states (Knox 1900: 414-418). Although a number of banks failed during the free banking era, the number of state banks increased from 901 in 1840 to 1,562 in 1860 (Knox 1900: 312).

It is considered that in NY, "some of the 'soundest' banking of the era was accomplished" around the period when the Free Banking Act was enacted in 1838 (Rockoff 1974: 163). In 1839, under the Free Banking Act, 71 free banks were in operation with a total banknote circulation of five million USD (Knox 1900: 416), while there were also 96 chartered state banks with a circulation of 19 million USD. Generally, the chartered state banks (e.g., the Bank of New York, the Bank of America, and the City Bank) were larger than the free banks (Knox 1900: 422, 427-429). The chartered state banks were under the "careful" supervision of the NY State Banking Department, and from 1840 the free banks were also subject to inspections by the Bank Commissioners (Knox 1900: 416-418, 422). ${ }^{6}$ In several states, the free banking system failed to attract investors willing to incorporate free banks. In Philadelphia, Pennsylvania, the free

\footnotetext{
${ }^{5}$ The Second Bank of the United States, one-fifth of whose capital was subscribed by the government, was liquidated in 1841 as a result of bad management.

${ }^{6}$ From 1843, the Comptroller of the State succeeded the Bank Commissioners.
} 
Table 2.1 Development of State and National banks in the US, 1834-1883 (10-year intervals)

\begin{tabular}{|c|c|c|c|c|c|c|}
\hline Year & 1834 & 1843 & 1853 & 1863 & 1873 & 1883 \\
\hline Number of state banks & 506 & 691 & 750 & 1,466 & 277 & 788 \\
\hline $\begin{array}{l}\text { Total deposits of state } \\
\text { banks ('000 USD) }\end{array}$ & 75,667 & 56,169 & 145,554 & 393,686 & 110,800 & 335,000 \\
\hline Number of national banks & - & - & - & - & 1,976 & 2,529 \\
\hline $\begin{array}{l}\text { Total deposits of national } \\
\text { banks ('000 USD) }\end{array}$ & - & - & - & - & 540,511 & $1,106,453$ \\
\hline $\begin{array}{l}\text { Population per state and } \\
\text { national bank }\end{array}$ & 29,476 & 27,900 & 34,876 & 23,435 & 19,163 & 16,374 \\
\hline $\begin{array}{l}\text { Total deposits of state and } \\
\text { national banks per capita } \\
\text { (USD) }\end{array}$ & 5.1 & 2.9 & 5.6 & 11.5 & 15.1 & 26.5 \\
\hline
\end{tabular}

Sources Knox (1900: 295-312); Robertson (1968: 67); Maddison Historical Statistics, Maddison Database 2010, https://www.rug.nl/ggdc/historicaldevelopment/maddison/releases/maddison-dat abase-2010, accessed on 18 April 2020

Note Because of data unavailability, figures for 1834 (rather than 1833) are shown

banking system was introduced in 1861, and yet only nine banks were incorporated under the system (Knox 1900: 460-461).

Between 1853 and 1863, the population per state bank fell from 35,000 to 23,000 , while the aggregate per capita deposits of the state banks increased from 5.6 USD to 11.5 USD (see Table 2.1). This suggests that by 1863 , the commercial banks were no longer mainly used by professional merchants. The advent of ordinary people as bank customers provided the background for the formalization of banking supervision.

\subsection{Progress of Commercial BANKING AND THE NATIONAL BANK ACT}

Neither the crisis of 1837 nor that of 1857 led to the formalization of bank regulation and supervision at the federal level. ${ }^{7}$ Triggered by the suspension of specie payments by New York banks, the crisis of 1837

\footnotetext{
${ }^{7}$ The bank obligation insurance program, which was similar to the deposit insurance system, was first adopted in NY in 1829, prior to the 1837 crisis (Federal Deposit Insurance Corporation 1998: 3-7).
} 
forced $25 \%$ of all banks to close (Rousseau 2002: 457-459, 486-487). Regarding the crisis of 1857, one important factor was the enactment of a regulation in New York in 1857 limiting the amount of notes that could be returned to peripheral banks, which resulted in a "flood of peripheral banks' notes into the city for redemption" (Calomiris and Schweikart 1991: 818-819). However, the scale and duration of the crisis were less than those of the 1837 crisis, with only five percent of banks failing, and some of those being able to resume operations soon after. Thus, recovery from the crisis of 1857 was "rapid" in New York (Calomiris and Schweikart 1991: 824-826).

Prior to the Civil War, both the North and the South needed large amounts of capital to finance their war efforts. When Salmon Portland Chase became Secretary of the Treasury in 1861, the fiscal disbursement required for war-related financing was huge. Chase preferred note issuing rather than an increase in taxation, and thus bonds were issued and sold, mainly to the general US population and companies, but also to speculators in Europe (e.g., in London and Amsterdam). ${ }^{8}$ From 1862, the Union government in the north issued a new paper currency, not fully backed by gold or other specie, as another source of financing. ${ }^{9}$ Thus, as much as 450 million dollars of legal tender known as "greenbacks" had been issued by the end of the Civil War.

Furthermore, as an element of wartime fiscal policy, Chase introduced a national bank organization plan that required banks to hold sufficient bond-secured banknotes because the market for government bonds was depressed at the time (Robertson 1968: 33-36). Following a period of discussion from December 1861 to February 1863, the use of a national currency backed by government bonds was incorporated into the National Currency Act of 1863 (Robertson 1968: 36-45).

In February 1863, the OCC was created under the general direction of the Secretary of the Treasury. The Comptroller was able to submit an annual report directly to Congress (i.e., not through the Secretary of the Treasury), and thus the OCC became basically an independent agency. Hugh McCulloch, who had previously been the president of the State Bank of Indiana, was appointed the first Comptroller (Robertson

\footnotetext{
${ }^{8}$ See Sexton (2005) for further details.

${ }^{9}$ The Confederacy government in the south also issued notes, some of which paid interest, but because of their less developed banking system and more limited access to the bond market, the Confederacy government's efforts were much less successful.
} 
1968: 45-47). Confronted with a disappointing start ${ }^{10}$ to the process of organizing national banks in place of the state banks during the period 1863-1864, McCulloch suggested a complete rewrite of the National Currency Act. Thus, the National Bank Act of $1864^{11}$ was passed by Congress on 3 June 1864 (Robertson 1968: 49).

Furthermore, the Act of 3 March 1865 imposing a ten percent tax on state banknotes created a significant incentive for state banks to join the national banking system. Consequently, 922 state banks were converted to national banks by 1865 (Knox 1900: 101). In Philadelphia, Pennsylvania, where the first national bank, The First National Bank of Philadelphia, was established, almost all of the state banks converted to national banks with the expectation of tax exemptions from the state government (Knox 1900: 461). Conversion from state to national also generated extra profits for the banks: National banks were no longer required to retain specie, and the converted banks could sell gold at the current price plus a premium. For example, the Philadelphia National Bank declared an extra dividend of $25 \%$ in 1866 (Wainwright 1953: 122-123).

From the 1870s, both the national and state banking systems developed significantly (see Table 2.1). The number of national banks increased from 1,976 in 1873 to 2,529 in 1883 (and to 3,787 in 1893), while aggregate deposits increased from 540 million USD in 1873 to 1,539 million USD in 1893 (Knox 1900: 295-304). Meanwhile, the rise of state banking was even more rapid, with the number of state banks increasing from 277 in 1873 to 3,579 in 1893, and aggregate deposits increasing from 110 million USD in 1873 to 709 million USD in 1893 (Knox 1900: 311-312). This state banking revival was related to the reduced profitability of the banks' note-issuing business from the 1870s onward (Robertson 1968: 62-68).

\footnotetext{
${ }^{10} \mathrm{McCulloch}$ identified four reasons for the disappointing start, especially the low rate of conversion from state banks to national banks. Among them, the rule whereby the word "national" should be included was an obstacle to conversion by state banks with their existing tradition and history (Robertson 1968: 47-49).

${ }^{11}$ The National Bank Act of 1864 was in part prompted by previous instances of bank misconduct (e.g., illegal note-issuing, speculation, excessive risk-taking, and fraudulent accounting).
} 


\subsection{Dissemination of Commercial BANKING REgulation}

US commercial banking regulation developed at both the national and state levels. ${ }^{12}$ The characteristic "dual banking system" of the US remains significant even today and was more or less predetermined by the signing of the US Constitution in 1787. The constitution granted the states considerable rights in terms of regulating business within their jurisdiction, which of course included commercial banking. Consequently, federal banking regulation before the creation of the national banking system in the 1860s was concerned with the near-central banks, namely, the First and Second Banks of the US, while private commercial banks were regulated by state authorities (Komai and Richardson 2011: 3).

Among early bank regulations in the US, a common feature was the charter requirement that provided state authorities with an opportunity to survey the prospects of a bank's owners, funding, and business model, both at incorporation and afterward (Mitchener and Jaremski 2014: 8-9). ${ }^{13}$ Demand for banking services grew rapidly from the 1830s onward in response to the rapid development of the US economy (see Table 2.1), and there were only loose constraints on the commercial banking sector. The formal requirements for obtaining a bank charter were undermined by political and commercial cronyism, whereby those with the right connections easily obtained a charter, while those without such ties found it much harder (Robertson 1968: 21-23).

During the free banking era, the number of state banks in the US increased from 788 in 1837 to 1,601 in 1861 (Robertson 1968: 16). During this period, the commercial banking sector experienced turbulence, with the average lifespan of a bank being approximately 5 years (Komai and Richardson 2011: 3). However, depositors' losses were relatively small because the banks were generally liquidated before their financial health had significantly deteriorated. Knox (1900: 315-316) estimated that total losses by noteholders were approximately five percent per annum, which was not particularly high given the rate of inflation at the

${ }^{12}$ See, for example, White (1983).

${ }^{13}$ Moreover, banks had to purchase government bonds or lend money to the state. 
time. Although 57 state banks failed during the free banking era in NY, 23 fully redeemed their circulating notes (Knox 1900: 322-323).

Federal bank regulation arose from the need for a common currency that had been recognized by most in the highest echelons of politics and business by the mid-1850s, and the creation of the national banking system was mainly aimed at improving the government's ability to cover the federal deficit caused by the Civil War. While the war was in progress, it had been less difficult for Congress to pass regulatory reforms because many of the strongest opponents of centralized authority were the southern states (Komai \& Richardson 2011: 3-4). Supported by the National Currency Act of 1863 and the National Bank Act of 1864, the US federal authority commenced its program aimed at regulating the commercial banks. ${ }^{14}$

Under the National Bank Act, national banks were regulated by the federal government based on a uniform set of rules. White (2015: 3-7) summarized the major regulations applicable to the national banks as follows. ${ }^{15}$

a) Minimum capital requirement (Sect. 7: $\$ 50,000$ for banks in towns with populations under 6,$000 ; \$ 100,000$ for those in larger towns with populations between 6,000 and 50,000 ; and $\$ 250,000$ for those in cities with populations greater than 50,000 )

b) Minimum reserve ratio (Sect. 31: 15\% of the total deposits and circulation for country banks, and $25 \%$ of the deposits for reserve city banks).

c) Circumscribed lending (Sects. 28-29: for example, no loan could exceed ten percent of the bank's capital stock)

d) Codified good corporate governance (Sects. 8-11: a minimum of five persons were required to form an organization; Sect. 40: banks were required to keep a list of names and residences of all of the shareholders available during business hours for inspection by any shareholder, creditor, and so on)

e) Double liability imposed on shareholders (Sect. 12)

f) Licensing and revocation power held by the Comptroller (Sects. 17$18,50)$

g) Quarterly disclosure requirements (Sect. 34).

\footnotetext{
${ }^{14}$ Notably, the national banking system did not replace the state-based banking systems.

${ }^{15} \mathrm{We}$ have made some minor corrections and added section numbers based on Robertson (1968: 195-212).
} 
The national banks were required by law to purchase and hold government bonds as collateral for the issuance of notes (new currency) almost equal to their value (White 2015: 3-4). Depending on the amount of collateral the bank had deposited with the US Treasury, the new currency was printed by the Treasury and then issued by the national banks. Thus, the US government guaranteed reimbursement of national banks' notes at par value via government bonds, ${ }^{16}$ while NY, for example, did not guarantee full payment of the notes of any state bank (Knox 1900: 95-96).

In an attempt to induce state banks to join the new national banking system, taxes on note issuing by state banks were introduced in $1865 .{ }^{17}$ This taxation was sufficiently effective to attract many state banks to become national banks, while state authorities responded by lowering the regulatory requirements (e.g., the minimum capital requirement) for obtaining a bank charter to attract small commercial banks. Over the following decades, the regulators and supervisors of both systems competed to attract commercial banks to join their system, leading to a form of "regulatory arbitrage" (White 2011: 6-9; White 2015: 4).

The banking crisis of 1907 led to another substantial reform of the US banking system, eventually resulting in the creation of the Federal Reserve System (FRS) in December 1913. The Fed, as the Federal Reserve was colloquially known, through its 12 Reserve Banks in various districts, was assigned a supervisory role in the sense that it had the authority to request financial information from the banks that joined the FRS with the aim of accessing the central bank's discount window. However, the Fed faced two dilemmas. First, it had to manage the conflict between price stability and financial stability. The US economy experienced high rates of inflation during the period 1914-1920, which forced the Fed to raise interest rates, which in turn induced the commercial banks to take greater risks (White 2011: 42-45). Second, the reforms created competition between the Fed and the OCC. The Fed attempted to attract both national and state banks to join the FRS by not imposing strict regulation

${ }^{16}$ If government bonds were in short supply, the US government simply increased the printing of its own bonds.

${ }^{17}$ However, a tax on state banknote issues in 1865 led the state banks to gradually shift their business model toward deposit-taking, while the federal currency-based national banks continued under the conventional business model until 1900 (Robertson 1968: $52-54,62-66)$. 
and supervision. The Fed basically depended on the bank examination reports provided by the OCC, but only limited reports were provided to the Fed. Later, the authority to request reports from the Fed's member banks was transferred from the OCC to the Fed, and the frequency of calls for reports halved following the introduction of the revised Federal Reserve Act of 1917 (White 2011: 34-40).

By the 1920s, the rise of branch banking had become a topic of debate. While only six percent of all commercial banks operated branches, those banks accounted for $15 \%$ of all commercial banking resources. Following a 3-year debate on whether unit banks should be protected from competition, the McFadden Act was introduced in 1927. This limited national banks to opening branches only within cities, towns, or villages where state banks were permitted to open new branches under state law (Robertson 1968: 100-105).

After the stock market crash of 1929 and the banking crises of the early 1930s, the liberal attitude of the US regulatory agencies toward the commercial banks was significantly transformed from a market-based discipline to a supervisory regime. The Federal Deposit Insurance Corporation (FDIC) was created in June 1933, and all of the Fed's member banks were required to join. By 1935, 43\% of the nation's deposits were insured by the mutual guarantee fund of the FDIC (White 2009: 25-26). Additionally, the FDIC was empowered to conduct bank examinations, albeit with considerable discretion. The Banking Act of 1933, widely known as the Glass-Steagall Act, included further restrictions on commercial banks, both state and national. The Glass-Steagall Act required the complete separation of investment banking and deposit taking, as investment banking was considered to carry higher risk. Based on the hard lessons of the preceding years, combining those businesses was considered inappropriate for individual depositors (White 2009: 27). The Fed's renowned Regulation Q of 1933 set interest rate ceilings for bank deposits, including term deposits (Allen et al. 1938: 418-419). Finally, under the Banking Act of 1935, the federal authorities were given the power to grant a bank charter. Specifically, the OCC stressed that a bank charter would not be granted unless the necessity for a new bank in the location and reasonable prospects of success were clearly evident (White 2009: 26). 


\subsection{Organization of the US Banking Supervisor}

Preceding the creation of the OCC, as Mitchener and Jaremski (2014: 11-13) noted, a separate authority for state bank supervision was created in several US states. By 1863, 15 states had an agency (generally state bank commissioners) with the stated objective of banking supervision. In many states, the creation of these supervisors was associated with the fact that the state government was either the sole or a partial shareholder in the commercial banks (Robertson 1968: 24-27). However, the overall quality of state banking supervision (e.g., publishing detailed standardized bank balance sheets for public examination) had not significantly improved by 1863 (Mitchener and Jaremski 2014: 24-25).

As part of the US Treasury, the OCC had its headquarters in the Treasury building. The Comptroller was appointed by the president based on the recommendation of the Treasury Secretary, with the Senate's approval. However, the operation of the OCC was reasonably independent (White 2011: 4-5). The OCC's Washington facilities (in the Treasury building) were funded by the federal government with US Congress approval, while the costs of on-site examinations were covered by examination fees charged to the examined banks. ${ }^{18}$

The first four heads of the OCC shaped the institution by establishing various priorities (Knox 1900: 97-105). The attitude of successive Comptrollers in the early years was one of caution in relation to risky (or illegal) behavior by the banks. ${ }^{19}$ The first Comptroller, Hugh McCulloch, maintained a conservative attitude and felt that it was his "duty" to discourage the organization of new banks to prevent "so much increase in the aggregate banking capital of the country." In 1865, McCulloch was appointed Secretary of the Treasury, and Freeman Clark became the second Comptroller. Because the national banknotes were printed by companies in New York, he recommended relocating the Comptroller's office from Washington DC to New York to enable prompt redemption of national banknotes, but this did not happen. In 1867, Hiland R. Hulburd succeeded Clark to become the third Comptroller. During his tenure,

\footnotetext{
${ }^{18}$ The examination fee was based on the examined bank's total capital (Robertson 1968: $78)$.

${ }^{19}$ This description of the first three comptrollers is based on the account of their successor Knox (1900). Thus, there might be some doubt regarding the veracity of his description. See also Kane (1922) for further details.
} 
Table 2.2 Burden of OCC bank examiners, 1889-1911

\begin{tabular}{lccccc}
\hline Year & 1889 & 1896 & 1903 & 1907 & 1911 \\
\hline Number of OCC examiners & 30 & 34 & 74 & 100 & 113 \\
Number of national banks & 3,239 & 3,689 & 4,935 & 6,422 & 7,270 \\
Number of banks per OCC examiner & 108.0 & 108.5 & 66.7 & 64.2 & 64.3 \\
\hline
\end{tabular}

Source White (2015: 11)

which ended in 1872, two important pieces of legislation were passed by Congress in 1869. First, instead of requiring reports from banks on the first day of January, April, July, and October each year, the OCC was permitted to call for a report on a bank's condition on any five days during the year to prevent the bank from taking measures to prepare a favorable report. Second, it became illegal for any person to support national banks in engaging in misconduct by any illegal measure.

In April 1872, John Jay Knox succeeded Hulburd to become the fourth Comptroller, a position he held until 1884. Although the national banking system was in fierce competition with the state banking system, and gradually adopted lax regulation and supervision practices, no formal deregulation process was implemented during the first decade of the dualbanking system. Legislation passed in 1876 authorized the appointment of receivers by the Comptroller to take charge in the case of insolvency or voluntary liquidation of a national bank. This also served as a means of law enforcement in cases involving the mismanagement of a national bank and/or violations of the law (Knox 1900: 110-111, 124-131; Robertson 1968: 72). The OCC now had the power to revoke a bank's charter and to place it in receivership if the bank was found to be insolvent.

White (2015: 11) noted that data on the number of examiners were available but incomplete (see Table 2.2). In 1889, the numbers of OCC bank examiners and national banks were 30 and 3,239, respectively, while in 1896 the numbers were 34 and 3,689, respectively. Because of the heavier than expected burden placed on bank examiners, various bank examination procedures, for example, submitting monthly bank examination reports, were often behind schedule (White 2015: 13-15). The number of banks per examiner ${ }^{20}$ was 108 in 1889 and 109 in 1896.

\footnotetext{
${ }^{20}$ Allen et al. (1938: 397-398) noted that each bank examiner was expected to carry out on-site examinations of 70 banks annually on average.
} 
The Federal Reserve System that was created in 1913 was assigned a supervisory role, with the main aim of scrutinizing the financial status of member banks for the purposes of the central bank's lending activities. However, the Fed was not empowered to access the complete examination reports sent by the OCC. The Fed's bank examiners were deployed to examine state-chartered member banks. There were six Fed examiners in 1915, which increased to 20 by 1920 (White 2011: 41-42). However, overlapping areas of authority led to tension between the Treasury (including the OCC) and the Fed, as the latter found it difficult to obtain complete independence from the former. In addition to the Fed being housed in the Treasury building, two of the Fed's board seats were held by the Comptroller and the Treasury Secretary, and hence those institutions had both insight into and influence over what the central bank was doing, and should be doing (White 2011: 35-40; Robertson 1968: 107-110).

The reforms of the post-Great Depression banking system led to stricter banking regulation, as well as the creation of several new organizations with supervisory objectives. Specifically, the FDIC undertook the task of bank examination. The FDIC was created in 1933 to administer the new deposit insurance scheme that would guarantee the repayment of deposits up to certain amount in the case of a bank failure. National banks were required to participate in this new deposit insurance system, and state banks were given the opportunity to join. However, prior to 1950, the FDIC was required to obtain written consent from either the Comptroller, the Board of Governors, or state supervisors, before it was permitted to conduct a bank examination (White 2009: 29).

Finally, the role of banking supervision was formally divided among the OCC, the Fed, and the FDIC in 1938 (Robertson 1968: 127). Moreover, the three agencies began to cooperate in relation to examination policies. For example, loans and investments were uniformly classified as Category I, II, III, or IV, replacing the previous approach to asset valuation that relied on the examiners' discretion (White 2009: 30). The bank examination procedures were made uniform among the three federal supervisory authorities (the OCC, the Fed, and the FDIC) and the state bank supervisory agencies in September 1938 (Suto 2003: 49-51). 


\subsection{BANKING SUPERVISION AND Characteristics OF THE OCC}

Before the emergence of the national banking system in 1863, state banks were subject to a certain level of supervision. The degree, frequency, and power of enforcement of this supervision varied from state to state but was generally characterized by a "light touch." As mentioned earlier, the double liability rule imposed on the banks' shareholders served to induce prudential operation. Thus, state bank examination "appears to have originated in those states where a stockholder relationship existed between the state and the bank" (Robertson 1968: 24). Information about the banks was reported sporadically to state officials, often following rumors about a bank being in financial distress. Several state supervisors even lacked the authority to force banks to provide even the most basic information about their business activities. If a bank was suspected of being close to bankruptcy, the governor would appoint one or more citizens who were held in high esteem to conduct an on-site examination (Robertson 1968: 23-27). This arrangement fits with most of the indicators of our definition of informal supervision including being sporadic, case-by-case, and discretionary (see Chapter 1).

The OCC was founded in 1863 and authorized to conduct regular on-site examinations of each national bank at least once a year and later twice yearly following a series of recessions in the early 1890s. On-site examinations took three days on average, or more precisely, one day for small country banks and five days for large city banks. The relatively low pay made it difficult to hire examiners' assistants, and the OCC's examiners also had to cover the travel expenses incurred in conducting on-site examinations (White 2015: 7-13).

The bank examination process can be summarized as follows. First, an examiner visited a bank with a bank examiners' book provided by the OCC containing pre-printed forms to record key information such as significant loans. Second, the examiner met with the board of directors and the president of the bank. Third, the examiner completed the official forms relating to the examination, and these were sent to the OCC office in Washington DC each month. Fourth, recommendations and suggestions were made to the bank if necessary, and the Comptroller persuaded the bank's board of directors to rectify any violations (White 2015: 15-17; Allen et al. 1938: 397-398; Robertson 1968: 71).

The OCC was empowered to revoke a bank charter and to place it in receivership if the bank was found to be insolvent. The power to approve, reject, or revoke bank charters was an important function 
of the Comptroller, who had few other disciplinary instruments (other than moral suasion) at his disposal. If an examiner discovered that loans had been granted in excess of the legal limits, the Comptroller had no means of addressing such a breach. Additionally, shortfalls in the reserve banks were required to hold were often treated as "random fluctuations." Examiners often found it difficult to estimate the value of collateral (especially real estate) for loans because they were required to exercise discretion in establishing values by referring to market prices. Some, but not all, commercial bankers viewed the OCC examinations as "a reasonably-priced nationally standardized audit" aimed at reducing the risk of contagion leading to runs on banks, and thus the relatively sound banks cooperated with the OCC in relation to examinations (White 2015: 17-19).

The main objective of the OCC's banking supervisory activities was restraining the abuse of privileges granted to banks under the federal charter. However, the evaluation of the banks' governance played another important role. The examiner's report considered the characteristics of the shareholders, directors, cashier, and the president of the bank, including a description of the internal auditing system. Loans to directors and officers of a bank received special attention from the bank examiners (White 2015: 20-21). Thus, over time, the OCC's supervisory function was transformed from the mere inspection of ledgers to close scrutiny of the operational status of the bank (Robertson 1968: 71-73).

Additionally, the OCC examiners occasionally endeavored to support a bank in severe financial distress. For example, the bank examiner's report regarding the Eighth National Bank of New York in December 1868 documented that the examiner had provided managerial advice to the bank's president aimed at improving the bank's fund-raising capability. ${ }^{21}$ The OCC was interested in the aftermath of bank failures, and the OCC annual reports included a list of failed banks, including the name of the receiver and dividends paid to shareholders. ${ }^{22}$

$$
* * *
$$

${ }^{21}$ Examiner's Report on the Eighth National Bank of New York, 19 December 1868, Failure in December 1871 of Three Banks in New York City, Committee on Banking and Currency, HR42A-F4.2, RG233, The US National Archives and Records Administration (NARA): Washington DC.

${ }^{22}$ For example, the OCC $(1872,1873)$ documented the problems identified in relation to the Eighth National Bank of New York. 
The formalization of banking supervision in the US occurred in incremental steps. In response to the state authorities' experiences of banking supervision during the free banking era, a national banking supervision system was established against a background of rapid social and economic development from the 1850s onward. The National Bank Act of 1864 was enacted to address the fiscal deficit incurred by the Federal government as a result of the Civil War, as well as to provide a uniform national currency. Thus, financial crises (e.g., the bank crisis of 1857) did not trigger this major step toward the formalization of banking supervision. However, following financial crises from the 1870s onward, even though these crises did not result in significant losses by either noteholders or depositors, the formal banking supervision system was strengthened incrementally. Specifically, the crisis of 1907 led to the creation of the Fed, which was empowered to examine member banks, and the Great Depression of 1929-1931 led to the creation of the FDIC, which was authorized to examine all national banks and state banks that participated in the federal insurance scheme. Further changes in relation to formal banking supervision by the OCC, the Fed, and the FDIC occurred in 1938, although the OCC continued to conduct on-site examinations on behalf of the FDIC until 1950.

Therefore, against the background of economic development the formalization of banking supervision in the US was triggered by the Civil War (i.e., for fiscal reasons) as well as the need to establish a national currency, while the formalization process was completed through measures introduced in response to a series of financial crises in the early twentieth century.

\section{REFERENCES}

Allen, A.M., S.R. Cope, L.J.H. Dark, and H.J. Witheridge. 1938. Commercial banking legislation and control. London: MacMillan and Co.

Allen, F., and D. Gale. 2000. Comparing financial systems. Cambridge, MA: MIT Press.

Calomiris, C.W., and L. Schweikart. 1991. The panic of 1857: Origins, transmission, and the containment. Journal of Economic History 51 (4): 807-834.

Federal Deposit Insurance Corporation. 1998. A brief history of deposit insurance in the United States. September. Paper presented at International Conference on Deposit Insurance, Washington DC. 
Gigliobianco A., and G. Toniolo, eds. 2009. Financial market regulation in the wake of financial crises: The historical experience. Workshops and Conference Publication 1, Bank of Italy, Rome

Goodhart, C.A.E. 2007. Financial supervision from an historical perspective: Was the development of supervision designed, or largely accidental? In The structure of financial regulation, ed. D.G. Mayes and G.E. Wood, 43-68. London: Routledge.

Grossman, R.S. 2010a. Unsettled account: The evolution of banking in the industrialized world since 1800. Princeton: Princeton University Press.

- 2010b. The emergence of central banks and banking supervision in comparative perspective. In State and financial systems in Europe and the USA: Historical perspectives on regulation and supervision in the nineteenth and twentieth century, ed. S. Stefano Battilossi and J. Reis, 123-138. Aldershot: Ashgate.

Haber, S. 2008. Political institutions and financial developments: Evidence from the political economy of bank regulation in Mexico and the United States. In Political institutions and financial development, ed. S. Haber, D.C. North, and B.R. Weingast, 10-59. Stanford, CA: Stanford University Press.

Hall, M.J.B. 1993. Banking regulation and supervision: A comparative study of the UK. USA and Japan: Edward Elgar Publishing, Aldershot.

Hall, P.A., and D.W. Soskice, eds. 2001. Varieties of capitalism: The institutional foundations of comparative advantage. Oxford: Oxford University Press.

Hammond, B. 1957. Banks and politics in America, from the revolution to the civil war. Princeton: Princeton University Press.

Hotori, E., and M. Wendschlag. 2019. The formalization of banking supervision in Japan and Sweden. Social Science Japan Journal 22 (2): 211-228.

Kane, T.P. 1922. The romance and tragedy of banking. Arno Press, New York, NY (reprinted in 1980)

Knox, J.J. 1900. A history of banking in the United States. Bradford Rhodes and Company, New York, NY.

Komai, A., and G. Richardson. 2011. A brief history of regulations regarding financial markets in the United States: 1789 to 2009. NBER Working Paper 17443.

Mitchener, K. 2005. Bank supervision, regulation, and instability during the great depression. Journal of Economic History 65 (1): 152-185.

- 2007. Are prudential supervision and regulation pillars of financial stability? Evidence from the great depression. Journal of Law and Economics 50 (2): 273-302.

Mitchener, K., and M. Jaremski. 2014. The evolution of bank supervision: Evidence from U.S. States. NBER Working Paper 20603. 
Office of the Comptroller of the Currency. 1872 [1873]. Annual report of the comptroller of the currency. Washington, DC: Office of the Comptroller of the Currency.

Robertson, R. 1968. The comptroller and bank supervision: A historical appraisal. Washington, DC: Office of the Comptroller of the Currency.

Rockoff, H. 1974. The free banking era: A reexamination. Journal of Money, Credit and Banking 6 (2): 141-167.

- 1975. Varieties of banking and regional economic development in the United States, 1840-1860. Journal of Economic History 35 (1): 161-181.

Rousseau, P.L. 2002. Jacksonian monetary policy, specie flows, and the panic of 1837. Journal of Economic History 62 (2): 457-488.

Sexton, J. 2005. Debtor diplomacy: Finance and American foreign relations in the Civil War era 1837-1873. Oxford: Oxford University Press.

Stiller, J., ed. 2017. Banking modern America: Studies in regulatory history. New York, NY: Routledge.

Suto, I. 2003. Daikyōko to amerika no kin'yū kisei: kiseigata sihonshugi to ginkō (The Great Depression and financial regulation in the US). In Kin'y $\bar{u}$ kisei ha naze hajimatta noka (Why financial regulation introduced), ed. E. Abe, 21-68. Nihon Keizai Hyoronsha, Tokyo.

Wainwright, N.B. 1953. History of the Philadelphia National Bank: A century and a half of Philadelphia banking 1803-1953. The Philadelphia National Bank, Philadelphia, PA

White, E.N. 1983. The regulation and reform of the American banking system, 1900-1929. Princeton, NJ: Princeton University Press.

- 1992. The comptroller and the transformation of American banking, 1960-1990. Washington, DC: Office of the Comptroller of the Currency.

2009. Lessons from the history of bank examination and supervision in the United States, 1863-2008. In Financial market regulation in the wake of financial crises: The historical experience, ed. A. Gigliobianco and G. Toniolo, 15-44. Rome: Bank of Italy.

2011. "To establish a more effective supervision of banking": How the birth of the Fed altered bank supervision. NBER Working Paper 16825.

- 2015. Stabilizing the national banking system 1864-1913: The role of bank examination. Paper presented at the 17th World Economic History Congress, Kyoto, 3-7 August 2015

. 2017. Stabilizing the national banking system 1864-1913: The role of bank examination. In Banking modern America: Studies in regulatory history, ed. J. Stiller, 67-87. New York, NY: Routledge. 
Open Access This chapter is licensed under the terms of the Creative Commons Attribution 4.0 International License (http://creativecommons.org/licenses/ by $/ 4.0 /$ ), which permits use, sharing, adaptation, distribution and reproduction in any medium or format, as long as you give appropriate credit to the original author(s) and the source, provide a link to the Creative Commons license and indicate if changes were made.

The images or other third party material in this chapter are included in the chapter's Creative Commons license, unless indicated otherwise in a credit line to the material. If material is not included in the chapter's Creative Commons license and your intended use is not permitted by statutory regulation or exceeds the permitted use, you will need to obtain permission directly from the copyright holder.

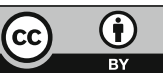

